\title{
Sublating Time: Hegel's speculative philosophy and digital aesthetics
}

\author{
Gareth Polmeer \\ School of Humanities \\ Royal College of Art \\ Kensington Gore \\ London SW7 2EU, UK
}

\begin{abstract}
In this paper I discuss G.W.F. Hegel's philosophy, arguing that the immanent, self-determining and dialectical movement of his 'speculative thinking' offers insights into contemporary aesthetics, the knowledge of reality, and of meaning in the transitoriness of the digital image. I relate speculative thinking as ontology to the ontology and temporality of the digital image, and focus my discussion around one of the central elements in Hegel's philosophy: 'sublation'. Contra postmodernism, Hegel's thought is shown to have critical contemporary import in defining reason and objective knowledge, and the value and interest of the work of art in the contexts of digital aesthetics.
\end{abstract}

Hegel. Dialectic. Sublation. Digital Aesthetics. Image. Time. Ontology.

\section{INTRODUCTION}

Sublation (Aufhebung) is a central concept in Hegel's philosophy, as it is to an understanding of his theory of art, and conception of reality as 'Spirit' (Geist) or the 'Absolute'. Sublation means variously and/or simultaneously to preserve, to make higher and to negate, and the sense in which it brings different elements into a unified whole is significant, both for questions of objective knowledge and truth (what Hegel terms the 'Idea'), and the way in which the work of art shows, in sensuous form, something universal about freedom and understanding, of both subjectivity and of the rational comprehension of reality (Spirit) (1975a).

Hegel's logic $(1969 ; 1975 b)$ expounds the truth of being in pure thought, giving an immanent and selfdetermining conceptual movement of the rational structure of reality. This he terms the logical, eternal or 'Absolute Idea'. Hegel further discusses the 'externality' of this logical Idea from pure thought into nature, space and time (1969, 843; 1970 ), and its development into socio-cultural forms where it has an 'actualization' $(1971,1)$ and is given life, and wherein humans recognise their own freedom and self-understanding as reciprocally determined and transcended within the movements and transformations of the whole, or 'Absolute Spirit' (1971). Hegel will show this to be explicable within human terms, through the self- determination and necessity of rational thought, or speculative philosophy, and crucially too, within the material sensuousness of the work of art.

\section{CONTEXT}

As an artist thinking through these questions, and of the relation of thinking to practice, my aims with this paper are to examine a selection of more abstract or theoretical questions around the possibilities of digital aesthetics (specifically the image), and the contemporary import of Hegel's philosophy, rather than discussing specific examples of work. What processes I do refer to have been channelled through my practice and will be framed in a consideration of the ontology of the image, and speculative philosophy as ontological. Absolute Spirit is constituted by three 'modes' of 'apprehension' for Hegel, of which art is accompanied by religion and philosophy (1969, 824). I have come to these questions primarily through artistic practice and aesthetic interests, and only latterly philosophically as such. These three modes have a critical interrelation in their means to convey truth, for Hegel, and thus a study of one brings relevant insights to the other.

Within the scope of this paper, and the broader connections I wish to make, my exposition of Hegel's philosophy will be necessarily limited. I have, nevertheless, aimed to render the frequently abstract and complex formulations of Hegel's 
thought perspicacious to the contexts of this conference, and in a prose suitable to the themes of digital aesthetics and electronic visualisation that it covers.

In one of the first texts of Hegel's that I read, the Science of Logic (1969), I was engaged to explore speculative philosophy in further depth. Here, in the very beginnings of logical development, Hegel uses a remarkable analogy to light and darkness (1969, 93) to explain the relation of 'being', 'nothing' and 'becoming'. Working with digital images, film, screens and projection, I found these analogies between knowledge and visual perception particularly profound, and this has led me to an aesthetic consideration of Hegel's logical thought and the concept of sublation, as well as further study of his aesthetics proper.

Hegel's speculative philosophy offers significant challenges to the orthodoxies and obscurities of postmodernism, and his philosophical conception of truth and objectivity - and the work of art as a form of its appearance - is a means by which various questions of contemporary media theory, digital aesthetics and knowledge might be interpreted. The texts by Hegel referenced in this paper were published between 1801 and 1835, yet the insights they contain are contemporary, prescient and relevant. An understanding of Hegel's thought has a further significant impact upon the variously popular philosophies underpinning the contemporary humanities by whom Hegel has been frequently misinterpreted or misunderstood. In this sense, whilst the anachronistic comparison of later art forms (digital media) to Hegel's aesthetics presents certain problems of interpretation and relevance, the universality or sense of truth that the artwork can convey still holds particular gravity, especially in a contemporary age where postmodernism and its legacies of nihilism, relativism and anti-humanism, are central in theorisations of digital aesthetics, and the arguments made therein for the transitory, meaninglessness and problems of knowledge.

Much postmodern theory proceeds on misconceptions of the Hegelian system, and the later developments of dialectic into, poststructuralism, Marxian thought or critical theory are often selective or erroneous. This has variously contributed to oversights of the study of Hegel's thought, and of its critical import. A number of scholars have sought to counter these views and also to reinterpret Hegel in light of these contexts (Houlgate, 2006; Maker, 1994) with J.N. Findlay writing for example, that '...there is nothing irrelevant nor uncontemporary in Hegel's ideas, and that he has as much to say to us as to previous generations of thinkers...'(1958, 20).
In the next section, I define Hegel's notions of sublation and the Idea, and their contexts within speculative philosophy and the Absolute (Section 3 ). This follows with an outline of the key aspects that follow from this into Hegel's aesthetics (Section 4 ), and a concluding section on sublation, time and the digital image (Section 5).

\section{SUBLATION AND THE ABSOLUTE}

Hegel's logic is immanent, self-determining and without presuppositions (Houlgate, 2006; Rosen, 2014), developing the knowledge of being from within pure thought as the 'self-movement' or 'activity' of negation, which forms opposition and contradiction into unity and a positive or speculative whole $(1969,442)$. Hegel terms this the 'scientific method of knowing' (Wissenschaft), 'metaphysics proper or purely speculative philosophy' $(1969,27)$, in which 'the necessary forms and selfdeterminations of thought are the content and the ultimate truth itself.' (1969, 50). Speculative philosophy is immanent, insofar as thought is selfdetermined in the course of its movement, and this movement also describes the essential nature of being. It is in this ontological sense that Hegel speaks of his science as metaphysics, insofar as what is thought accords with being, or what is real (1975b, 36). As Stephen Houlgate explains, Hegel's is an 'ontological logic that determines what it is to be by determining what it is to think.' (2006, 125).

Hegel is critical of the historical conception of metaphysics, and of the 'Understanding' (Verstand) insofar as it presupposes categories for philosophy, is dualistic or sets limits on knowledge (1975b, 113121). In critiquing and developing these questions, his form of speculative reason (Vernunft) is described as 'the grasping of opposites in their unity or of the positive in the negative' $(1969,56)$ and of the whole or Absolute, that it is the identity of identity and non-identity; being opposed and being one are both together in it.' (1977b, 156). These terms are closely related to sublation, as will be explained further below, and to what Stanley Rosen terms the "identity of identity and difference"', explaining that 'the identity of the world (= the whole) is not in addition to, but is essentially defined by, the non-identity or difference between one unit and another.' $(2014,16)$. Hegel explains that

To sublate, and the sublated...constitute one of the most important notions in philosophy. It is a fundamental determination which repeatedly occurs throughout the whole of philosophy...'To sublate' has a twofold meaning in the language: on the one hand it means to preserve, to maintain, and equally it also means to cause to cease, to put an end to...Something is sublated 
only in so far as it has entered into unity with its opposite... (1969, 106-107)

It is in this opposition and unity that sublation can be more fully comprehended, and the complex ideas in Hegel's thought rendered clearer through the integrity of the term to his overall philosophy. Hegel explains that the process of speculative philosophy, or the whole, is thus the positive and the negative, of opposites in a form of interconnected and immanent determination, and this is the movement of thinking and the form of reality $(1977 a, 36)$.

Hegel distinguishes his science, or speculative thinking, from the broader conception of science, and his idea of truth develops by what speculative thinking determines immanently. It is in this sense that he writes of 'the proper immanent development of the thing itself' $(2008,18)$ and to be 'immersed in the material, and advancing with its movement... (1977a, 32). Rather than bring in rules extraneous to the subject matter, or apply categories from other disciplines or sciences 'speculative thinking has to demonstrate each of its objects and the explication of them, in their absolute necessity.' $(1971,5)$.

For Hegel therefore, 'The True is the whole.' (1977a, 11), in which positive and negative, identity and non-identity are united and sublated. He thus defines what is 'actual' (reality/being) and what is 'rational' (thinking) within the conceptual interrelations of logic $(2008,14)$ insofar as 'selfconscious reason' is consonant with the structure of reality, or as he puts it 'reason which is in the world' (1975b, 8). This, as Houlgate explains 'means that being is in itself intelligible logical form and that thought is the direct awareness of such intelligible being.' $(2006,117)$.

It is a misunderstanding to think that Hegel means by the rational/actual explanation that the world is wholly within the subjective, as it were,, for the varied discussions across his work show his distinct attention to materiality, nature and the relation of subject and object. His philosophy is the critical exposition of knowing reality and nature, and of showing this to be understandable by human reason; that is to show how humans are both part of material nature, but also mediate and reflect their humanity through it, and in developing reason to its highest possible points - in the work of art, for example - showing the unique sense of freedom, and truth that humans hold.

Hegel terms the fully logical understanding of being the 'Absolute Idea': the self-determination and freedom of reason, which describes the nature of being from within the immanent activity of dialectical, logical development (1969, 824-844).
Hegel writes that 'Nothing is alive which is not in some way or other Idea.' $(2008,17)$, and it is the Idea which forms the shared relation between thought and reality. Hegel's Science of Logic, Rosen explains

\begin{abstract}
is the pure thinking, not of static logical form as distinct from subjectivity, but of the conceptual development of the process of spirit, that is, of the life-pulse or unity of being and thinking. The conceptual moments of this process are accordingly alive; they are self-moving and interactive. $(2014,71)$.
\end{abstract}

Thought is thus ontologically related to the movements of the dynamic natural world out of which it evolves and becomes self-conscious. This is moved by negation $(1977 \mathrm{a}, 10,19)$, what Hegel terms 'the innermost source of all activity, of all animate and spiritual self-movement, the dialectical soul that everything true possesses and through which alone it is true...' (Hegel 1969, 835).

Hegel's philosophy thus includes what is negated, as part of truth or reality, and something has life he argues, only insofar as affirmation and negation are dialectically related and sublated (Hegel 1975a, 97). Dialectic is immanent to the movement of Hegel's science, it is what gives it necessity, and interconnection (1975b, 116), and importantly too, it is the motion of sublation, such that the 'dialectical advance...carries along with it all it has gained, and inwardly enriches and consolidates itself. (1969, 840). The moments that constitute this are the interconnection and dynamic of its parts, or the 'movement of the whole' (1977a, 17).

Hegel variously discusses sublation in analogies to circularity and organic life. He writes of 'one organic totality' (1975a, 24), that 'Philosophy...circles back into itself.' (2008, 18), of 'self-movements, circles...an organic whole...'(1977a, 20), or that '...science exhibits itself as a circle returning upon itself...' (1969, 842). In Hegel's system, as Michael Inwood comments, 'the world is a circle of successively sublated conditions.' (1992, 124). Hegel writes of a plant through its growth, where 'mutually incompatible' parts have a 'fluid nature' that 'makes them moments of an organic unity...the life of the whole.' (1977a, 2). The plant develops and changes, but remains immanent and in unity (Hegel 2008, 17), and Hegel connects this analogy to the idea of immanent, conceptual selfdevelopment and process in speculative thinking. (1975b, 224).

Findlay comments that the Absolute is 'thoroughly shown to exist only as revealed in human experience. $(1958,20)$, and in this sense, it is in everyday processes, and the organic, material world in which what is Absolute can be discovered. Hegel stipulates that 'What philosophy has to do 
with is always something concrete and in the highest sense present.' (1975b, 138) and that it cannot 'transcend its contemporary world' (2008, 15). Thus when he speaks of the 'eternal Idea' at work in the Absolute (1971, 315), that 'the Idea, Spirit, is eternal.' (1970, 35), or that 'Eternity will not come to be, nor was it, but it is' $(1970,36)$, he explains the truth of being in the present, of knowing reality as comprehensible within human intelligence and experience. This is both a profound and complex idea, and speaks to a sense of ontological truth, and of the very nature of reality itself, something which, for Hegel, can be achieved in the highest means of human thought, and importantly too, in the work of art.

Hegel distinguishes between 'timelessness' (eternity) which is what 'endures', and 'duration' or what is finite or processual (and thereby temporal). 'The Idea, Spirit, transcends time...it is eternal...', he writes because it is what is determined in pure thought or logic, and thereby knows being itself. $(1970,36)$. The logical Idea within pure thought is thereby 'infinite' $(1969,825 ; 1971,23-24$; 1975b, 49). But, to recall Hegel's sense of what is concrete or present, this cannot be known except within the perspective of the finite, contemporary world. Rosen variously expounds the complexity of this relation suggesting that 'Eternity is the Aufhebung of the eternal and the temporal.... In human terms, experience is both logical and historical.' (1974, 134 ), and by showing that history and eternity are sublated in the Absolute (2014, 89, 298). Hegel thus writes that 'The important thing, then, is to recognize in the semblance of the temporal and transient the substance which is immanent and the eternal which is present.' $(2008,14)$.

The ontological forms that constitute knowledge of reality (and reality itself) can be developed within dialectical/logical thought (the Idea), and it is the means by which this moves into the world of nature and culture in Spirit, that knowledge is fully realised. In this sense, as Hegel writes, "truth exists only as knowing consciousness, as spirit confronting itself as spirit.' (1975a, 144), or as Rosen summarises the point, 'In knowing itself, spirit knows the world.' $(2014,46)$.

Alongside philosophy, the work of art is one of the other central means by which Spirit and knowledge manifest in human activity, and in the way that the Idea takes on a sensuous appearance, it too, can suggest something of this 'eternal' sense of truth. In its giving permanence to transitoriness, the art work indicates the Idea as the eternal, or truth, in its material, form and processes. It is to a discussion of aspects of Hegel's aesthetic theory that I will now turn.

\section{HEGEL'S AESTHETICS}

Recalling the earlier discussion of the organic whole, Hegel writes that 'Every philosophy is complete in itself, and like an authentic work of art, carries the totality within itself.' (1977b, 89). In the same way that logic must be immanent and selfdetermining, and in the manner in which it must sublate positive and negative into a unity, so too with art, Hegel speaks of the 'essential inner progress of its content and means of expression' and of its 'necessary formation.' (Hegel 1975a, 12).

The Idea is the logical truth of being, but Hegel writes, it 'should realize itself externally and win a specific and present existence as the objectivity of nature and spirit.' $(1975 \mathrm{a}, 111)$. This is what is expounded across the three-parts of Hegel's science - Logic [1] (1975b), Nature [2] (1970), and Mind/Spirit [3] (1971). The Idea into external existence is Absolute Spirit, and it is this that embodies the highest sense of freedom, truth and self-understanding $(1971,292-315)$. The Idea is to 'transpose' into nature and 'free itself' to become 'spirit in its eternity and truth.' (1975a, 94), Hegel writes, and in this way he describes three 'forms' (1975a, 101) or 'modes' $(1969,824)$ of which Absolute Spirit is constituted: art, religion and philosophy. It is to the latter that he ascribes the 'highest mode' of the Idea (1969, 824). For Hegel therefore, philosophy is the highest means by which truth and understanding can be gained.

Art, for Hegel 'has an end and aim in itself' (1975a, 25) and as such it is not to be considered prescriptively $(1975 \mathrm{a}, 18)$, but in terms of what its freedom can be, and how, like reason it can be self-determined $(1975 a, 7)$. Its purpose is to show beauty, and the highest sense of human freedom and self-understanding. As the 'sensuous presentation of the Absolute itself' (1975a, 70), art shapes Spirit into wholeness, insofar as humans become aware of their being with reality, and of spirit, and make works of art out of this, in the sense of self-awareness and truth.

For Hegel, 'eternity' is the purely logical Idea, but this is actualised in the present and realised in Spirit; that is, in historical terms, and the material form of the work of art in which the Idea appears in sensuous form. Here, transitoriness is suspended into a form of permanence, such that 'the work of art persists' he writes, not as 'mere permanence...but its having made spiritual inspiration conspicuous.' (Hegel 1975a, 29).

The work of art is physically impermanent or finite, the digital image seemingly more so (a point to which I will return), but its content and form, its sensuous particularisation of thought and Spirit into an artistic object, indicates its bringing something 
enduring out of transience. The relation between its form and content makes Spirit, or what is 'eternal' present within this finitude. This is the dialectical movement of thinking the relation of reason to the sensuous object, in that it is developed through the artwork's form, and is thus an object for reflection, that is at once external and internal - in our seeing its connection of the intellectual and sensorial nature of human life. The work of art for Hegel, is something sensuously particular, in which particularity is able to express something universal or Absolute (1975a, 22). Spirit develops in art in a sensuous form, therefore (1975a, 39) and as with the movement of logic and the positive and negative, art too sublates opposition and difference (1975a, 55).

In explaining the historical development of history, or Spirit, through the human development of art forms, Hegel describes the move from art's highest mode of aesthetic significance through to the elevation of philosophy or reflection. This is explained across the timeline of what he terms 'Symbolic', 'Classical' and 'Romantic Art', and the varied arts of architecture, sculpture, painting, music and poetry (1975a, 75-90). Hegel's discussion of art is also conceived of in terms of sublation, and of the positive and the negative, such that the negative must be engaged within the activity and form of the work of art and its making, if it is to show truth. It is in the alienation and contradictions of modern culture, between human freedom and nature's determinations, and between subjectivity and objectivity that the work of art gains significance (1975a, 54), and beauty - as the form in which the Idea appears sensuously (as 'Ideal') $(1975 a, 106)$ - is where such tensions or oppositions are sublated. Beauty therefore, is in 'the absolute realm of the Idea and its truth.' $(1975 a, 115)$. Hegel writes that the beauty of art is greater than the beauty of nature, insofar as it fulfils in the natural world what is human, or spiritual, in this having been made in the aesthetic form of an object, and moreover an object of beauty, in its highest sense (1975a, 2).

Contemporary interpretations of Hegel's aesthetics, as with his logic or philosophy of nature, vary significantly, from those of various philosophical backgrounds and interests. The varied importance and significance of Hegel's aesthetics to contemporary debates is widely discussed (Maker, 2000), and one of the most significant aspects contested is Hegel's argument that whilst being one of the highest forms of spirit, 'art, considered in its highest vocation, is and remains for us a thing of the past.' (1975a, 10-11).

The precise meanings of this thesis are widely discussed and variously debated. Hegel's own different perspectives on this question indicate the elevation to which he holds beauty and the work of art (1975a, 94), and in which, if truth is be fully conceived in the sense of the Idea, it must develop from pure thought into nature and social life, to realise itself, as such. Nevertheless, the sense in which he holds philosophy as the highest knowledge of truth, is the logical Idea (1969, 824844; 1971, 292-315). As William Desmond has argued, Hegel's sense of positioning art below religion and philosophy, should itself be considered through sublation $(1986,16)$. Given the sense of interconnection within the modes of Absolute Spirit, one might look to these matters within the sense of preservation and negation, circularity and wholeness, to see, as Desmond puts it, that 'this necessitates a real openness of philosophical thought to art.' (1986, xx). As Houlgate comments on this matter too, Hegel's aesthetics show 'the distinctive value of art in the modern world', and that 'Art may no longer be the highest form of human self-consciousness, for Hegel, but it still has great value in the modern reflective age...' (2005, 240).

One important line of interpretation on Hegel's contemporary relevance has been to examine the relations between his logic and aesthetics, in the sense that Hegel speaks of this in his own analogies to music, for example (1969, 368-369; 1975b, 160, 1977a, 38); in comparing his philosophical style to a work of art; and in exploring the interconnections between art, religion and philosophy as shared forms of Absolute Spirit.

Desmond argues that the work of art can be understood as 'an aesthetic concretion of Hegel's general principle of Aufhebung.' $(1986,64)$, and he sheds significant light and critical interest on the connections between conceptuality and sensuousness in Hegel's aesthetics, the interconnections between immanence and selfdetermination in logic, time and eternity, and the way that Hegel formulates his conception of art's own necessity and freedom to show the truth of being. Desmond writes of 'the kinship of the art work and the philosophical concept in Hegel...' $(1986,13)$, and of the 'ontological weight' that the artwork carries, in its being part of Absolute Spirit. $(1986,20)$.

Jere Surber has also suggested affinities between systematic science and aesthetics, insofar as Hegel's thought, he writes, points towards 'artistic production as itself a philosophically viable (if not entirely autonomous) mode of thought.' $(2000,46)$, and in 'blurring the boundary between artistic practice and philosophical theory.' (2000, 57). Surber suggests such relations through the contexts of music and temporality, and it has been with these associations that others have commented on Hegel's logic in an aesthetic sense 
too. Theodor W. Adorno makes various comparisons between speculative philosophy, film/photography and music (1993, 91, 99, 123) for example, as does Findlay $(1958,68,148)$ who suggests, in a striking analogy, that speculative reason involves

something like the experienced iridescence where slight shifts of vision reveal startlingly new colours, or something like the experienced combination of incompatible viewpoints which occurs in stereoscopic or stroboscopic vision. (In Hegel 1975b, xvii)

The associations between Hegel's philosophy and the language of images and optics, have, in my own practice with the digital image, been one means to reflect upon the contemporary import of Hegel's thought, and the relation of philosophy and art, theory and practice.

\section{SUBLATING THE IMAGE IN TIME}

In the Science of Logic, to recall my introductory comments, there appears a section where Hegel's language draws analogies between logic and light. He writes that

\begin{abstract}
in absolute clearness there is seen just as much, and as little, as in absolute darkness...Pure light and pure darkness are two voids which are the same thing...it is only darkened light and illuminated darkness which have within themselves the moment of difference...(1969, 93)
\end{abstract}

Whilst anachronistic, there is something remarkable in a contemporary reading of this text, suggesting shifting videographics, the determination of light within display technologies, or the aesthetic choices of the artist in rendering phenomena visible in the digital image. Hegel is here developing the relation of 'being' and 'nothing' at the very beginning of his logic, insofar as it is in their unification and difference, or their 'becoming', in which they develop and are determined. In the analogy used by Hegel, light and darkness, are sublated in their interrelation as such, insofar as their identity is the condition of their non-identity, and together these form the possibility of a form of vision, and of knowing, so to speak.

In this sense the variously processual nature of the digital image and its time-base might be termed a kind of sublation, insofar as the 'within' of light and darkness that Hegel describes is the point at which preservation and negation occur, and in which the tensions of these moments are leveraged for their crucial relation and difference. This has important possibilities for the interrelation of theory and practice, in that it brings to view the questions of digital aesthetics, both literal (in the sense of pixels, projections or screens) and analogical (in the sense of light and darkness representing questions of meaning). Sublation is a logical category for Hegel, but is also the actual, dialectical nature of being. Thus for the art work to embody this is to unite the rationality that is in reality, with the way that reason actualises or makes present this rational structure of reality, or the ontological truth of their relation, which is the Idea. In this way, one might preserve, negate or elevate sublation in its particularity and movements within the form of the work of art and the way it mediates phenomena into form and content.

Pure light and pure darkness can be seen to encapsulate what is key in sublation, of the complexity of the wholeness of human experience and of reality, and the self-awareness of fulfilling that experience in its highest sense of reason, or the Idea. If the whole or totality, in Hegel's terms, is the unity of opposites, then neither light, nor darkness alone are adequate for understanding. If light is identity, and darkness, non-identity, they are, as opposites, themselves in further identity with one another, and only become determined by one another, and it is this that interrelates to form a type of seeing, meaning and truth.

There is something of importance here in the question of optics and digital aesthetics. Hegel's analogy can indicate, ontologically, the way that the digital image is variously sublated. This might be described across four interacting levels: the technological, the representational, the historical and the artistic. In the technological sense the digital image is time-based (even when it is still, as such) and is predicated on its constant differentiation, as millions of pixels flicker in nanoseconds at varied luminance in the complex spatiotemporal matrix of the pixel grid. The image is constituted in singularity or identity out of millions of others. On the representational level, the algorithms used to encode the developing image have a complex spatiotemporal function too, insofar as forms of prediction and sampling constitute the 'now' from accumulated aspects of the image past, as well as in estimating what will come next. This is further related to the content, be it computergenerated, or camera recorded. Thus, past, present and future are simultaneously sublated in its moments, creating a complexly multi-temporal 'now' from multiple times, as it were. The instant or the frame is thus still or positively present, and also moving and negated, and is constituted or sublated in the relation of the two.

On the historical level, the prevalence of production by solely digital means, and the digitisation of historical, analogue materials, is an equivalency or identicalness of images into a code-based form. But this has within it an essence of difference or 
non-identity also, insofar as its restructuring or presentation is not given, and is open to configuration and aesthetic possibility. Leading from this to a fourth level of these preceding forms, might be added an artistic phase, in which all of the possibilities contained in the latter can be channelled or sublated through the form of the art work, and the processes or aesthetic choices brought about by the artist, and how the artist configures digital data into light or sound that sublates the abstract uniformity of code back to sensuous difference. This is the most important phase for the purposes of this discussion, given that interaction with one of the aforementioned elements, taken in the context of the whole, has an intrinsic effect on the others.

The digital image might be thought within some of the intersections of Hegel's descriptions of music and painting, particularly as this relates to the way in which phenomena are rendered into the planarity of a surface, and the manner in which this spatial aspect develops into time (1975a, 87-89). In my own video work, I have sought to explore interests that connect with the aesthetics of film and painting, and the form and temporality of the movement of colour in the digital image, as well as sequencing and composition comparable to the scores or rhythmic notions of music.

In this respect, another remarkable section of the Science of Logic is relevant, where Hegel speaks of motion in the terms of the sublation of what is 'here and not here', insofar as stillness and movement are simultaneously determined or in a contradictory development within one another, and are unified in this relation $(1969,440)$. Alongside Hegel's analogies to light and darkness, this has also informed my thinking on practice, of my own analogies of dialectic to the moving image, and of how to embody this sense of the sublation of time within the sensuous form of the digital image, when it already has a complex temporal instability, or immanent movement of preservation and negation of its own.

That the digital image is therefore always temporal, in its refreshing and updating, and in its linear progression of lines and frames, seems to indicate that nothing in it has permanence. In this way, and if this form of negation is something ever present to the digital image in time, I have sought to negate it in turn, in the sense of immanently working through the aesthetic possibilities of the image's form, to sublate time within it, and thus to activate not only what is negated or transitory, but what in it is preserved or suggests something higher.

This occurs within numerous processes, and I have variously used complex forms of layering and sequencing to develop images where there is a certain 'infinity' or qualitative variation developed out of the finite or quantitative material formation of the work. I have sought to explore something that suggests the infinite or enduring, within the temporal finitude of the art work in time; that multiple times and spaces are developed, and develop through and determine one another, such that what appears is an 'infinite' image space that opens for contemplation and reflection, but that is nonetheless and importantly present, and intrinsically revealed only through the material processes of light and colour. The degree to which my own work is consonant with Hegel's own interest in art remains something unresolved for me, and a point of continuing reflection. However I have not sought to adhere in any particular doctrinal or prescriptive way to finding a consonance, and have instead worked through what I take to be the most immanent and compelling ideas that the work presents, and to engage this with a sense of autonomy and form, that is itself immanent, and self-determining.

If sublation means to look to the positive as well as the negative, and to see something higher still from this, then many recent artists and theorists have very readily equated the intangibility and transitoriness of digital media, and the flicker of electronic light only in a wholly negative sense, and with a loss of meaning. But as Hegel shows, this in itself can still give us cause to see something 'eternal' within the ephemeral, and to understand the ephemeral within a form of permanence through the sense of sublation. Beyond the mere appearances of the 'transitory world', Hegel writes, the work of art gives passing phenomena a 'higher actuality', a 'pure appearance' that 'points through and beyond itself, and itself hints at something spiritual of which it is to give us an idea...'(1975a, 9)

The work of art embodies a sense of what endures, not just through the semi-permanence of its materials, or the aesthetic form in which experience is rendered. It is in its mediating the relation between thought and sensuous reality, and in doing so showing what is true, or eternal, so to speak amidst the transitory. In the terms of digital aesthetics, where the virtual is usually considered as the equivalent of a kind of false appearance or illusion (a dualistic world) the 'pure appearance' of art is the form of the beautiful (1975a, 4), as Hegel writes, and this shows a sense of what is 'infinite and free' $(1975 a, 112)$, rather than obscuring our knowledge or vision.

The potential of the digital artwork is that it can sublate time, and the duration of its temporal instability, of the pixels that flicker and fluctuate in ceaseless motion, and from that transitoriness still show something that is timeless, as such. To 
sublate time in the artwork is to posit the critical point between permanence and transience, or rather to see that both are intrinsically connected. It is important to recall that Hegel proposes such an eternal sense of knowledge within human terms, and whilst the art work, within its possibilities, might transcend or elevate our self-understanding, it does so as a condition of the whole, which is negation and the movement of this in sublation.

I have only been able to outline some of the key questions that arise from the contemporary reconsideration of Hegel's philosophy, and of the contexts of his aesthetic theory to digital aesthetics. His thought is difficult and complex, and in this I have tried to show that there is a sense of the concrete and the human underlying his claims to self-understanding, reason and beauty in the work of art. If a Hegelian form of digital aesthetics is possible, and if the work of art can be thought of again in some of the highest senses of human understanding that Hegel suggests, then the approach now, amidst the legacies of relativism and technological determinism in art theory and practice, must be an active one, in which the production of the work must be of an immanent necessity. Here the very properties of the digital image - its appearance and transitoriness - might be inverted (or sublated), insofar as appearance can be seen as that of beauty, or truth, and transitoriness in its dialectical movement with what is lasting.

The temporal possibility of the digital image shows that to sublate the time within it, opens valuable questions about knowledge and being. These questions would have to be both specific to the technological and artistic questions posed by the digital age, but also to the realisation of the history and culture contained and sublated within it. As with Hegel's sense of the historical movement of Spirit, and of the relation of philosophy to aesthetics, this might indicate the humanism, beauty and possibilities of the work of art, showing what is lasting, of value and 'eternal', within the transient time of the digital present.

\section{REFERENCES}

Adorno, T. W. (1993) Hegel: Three Studies. Trans. S. Weber Nicholsen. MIT Press, Cambridge.

Desmond, W. (1986) Art and the Absolute: A Study of Hegel's Aesthetics. State University of New York Press, Albany.

Findlay, J. N. (1958) Hegel: A Re-examination. George Allen and Unwin, London.

Hegel, G. W. F. (1969) Hegel's Science of Logic. Trans. A.V. Miller. Humanity Books, Amherst, NY.
Hegel, G. W. F. (1970) Hegel's Philosophy of Nature, Part Two of the Encyclopaedia of the Philosophical Sciences. Trans. A.V. Miller. Oxford University Press, Oxford.

Hegel, G. W. F. (1971) Hegel's Philosophy of Mind, Part Three of the Encyclopaedia of the Philosophical Sciences. Trans. W. Wallace and A.V. Miller. Oxford University Press, Oxford.

Hegel, G. W. F. (1975a) Hegel's Aesthetics: Lectures on Fine Art, Volume 1. Trans. T.M. Knox. Oxford University Press, Oxford.

Hegel, G. W. F. (1975b) Hegel's Logic, Part One of the Encyclopaedia of the Philosophical Sciences. Trans. W. Wallace. Oxford University Press, Oxford.

Hegel, G. W. F. (1977a) Hegel's Phenomenology of Spirit. Trans. A.V. Miller. Oxford University Press, Oxford.

Hegel, G. W. F. (1977b) The Difference Between Fichte's and Schelling's System of Philosophy. Trans. W. Cerf. State University of New York, Albany, NY.

Hegel, G. W. F. (2008) Outlines of the Philosophy of Right. Trans. T.M. Knox. Ed. S. Houlgate. Oxford University Press.

Houlgate, S. (2005) An Introduction to Hegel: Freedom, Truth and History. Blackwell Publishing, Oxford.

Houlgate, S. (2006) The Opening of Hegel's Logic: From Being to Infinity. Purdue University Press, West Lafayette, IN.

Inwood, M. (1992) A Hegel Dictionary. Blackwell Publishers, Malden, MA.

Maker, W. (1994) Philosophy Without Foundations: Rethinking Hegel. State University of New York Press, Albany.

Maker, W. (ed.) (2000) Hegel and Aesthetics. State University of New York Press, Albany.

Rosen, S. (1974) G.W.F. Hegel: An Introduction to the Science of Wisdom. Yale University Press, London.

Rosen, S. (2014) The Idea of Hegel's Science of Logic. The University of Chicago Press, Chicago.

Surber, J. (2000) Art as Mode of Thought. In Maker, W. (ed.), Hegel and Aesthetics. State University of New York Press, Albany. 